\title{
Effect of replacing soybean meal protein with protein from upland cottonseed, Pima cottonseed, or extruded Pima cottonseed on production of lactating dairy cows ${ }^{1}$
}

\author{
G. A. Broderick, ${ }^{\star 2}$ T. M. Kerkman,† H. M. Sullivan, $\ddagger$ M. K. Dowd,§ and P. A. Funk\# \\ ${ }^{*}$ Agricultural Research Service, US Department of Agriculture, US Dairy Forage Research Center, 1925 Linden Drive, Madison, WI 53706 \\ †EcoSol LLC, Tucson, AZ 85719 \\ ‡Eastern Laboratory Services, Medina, $\mathrm{OH} 44256$ \\ §Agricultural Research Service, US Department of Agriculture, New Orleans, LA 70124 \\ \#Agricultural Research Service, US Department of Agriculture, Mesilla Park, NM 88047
}

\begin{abstract}
Pima cotton production is increasing in the United States, but Pima cottonseed generally contains higher concentrations of the antinutritive pigment gossypol than conventional upland cottonseed. Heating promotes the reaction of gossypol with protein, reducing gossypol absorption and toxicity. The objective of this study was to assess the nutritional value for dairy cattle of Pima cottonseed cake (PCSC) that was heated and oil largely removed by an experimental extrusion process, compared with upland cottonseed (UCS) and Pima cottonseed (PCS). The PCS had greater crude protein $(\mathrm{CP})$ and ether extract, less neutral detergent fiber (NDF) and acid detergent fiber (ADF), similar total gossypol, but higher (-)-gossypol isomer compared with UCS. Extrusion reduced lipid content by $73 \%$, increased concentrations of $\mathrm{CP}, \mathrm{NDF}$, and $\mathrm{ADF}$, and reduced total gossypol, (+)-gossypol, and (-)-gossypol in PCSC versus PCS. Forty lactating Holsteins (8 with ruminal cannulas) were blocked by days in milk into 5 squares in a replicated, incomplete $8 \times 8$ Latin square, and were fed diets containing, on a dry matter (DM) basis, $30 \%$ alfalfa silage, $31 \%$ corn silage, 21 to $25 \%$ high-moisture corn, and about 15\% CP. Diets were fed as total mixed rations for ad libitum intake. Supplemental CP was from (1) solvent soybean meal (SSBM) only or $50 \%$ from SSBM plus $50 \%$ from (2) UCS, (3) PCS, (4) PCSC, (5) UCS plus PCS, and (6) UCS plus PCSC, or (7) 50\% from expeller soybean meal (ESBM) plus $50 \%$ from PCS, and (8) $50 \%$ from ESBM plus $50 \%$ from PCSC. Periods were 4 wk long (total of 16

\footnotetext{
Received May 13, 2012.

Accepted November 16, 2012.

${ }^{1}$ Mention of any trademark or proprietary product in this paper

${ }^{2}$ Corresponding author: glen.broderick@ars.usda.gov
} does not constitute a guarantee or warranty of the product by the US Department of Agriculture or the Agricultural Research Service and does not imply its approval to the exclusion of other products that also may be suitable.
\end{abstract}

wk); production data were collected over the last $2 \mathrm{wk}$ and blood and ruminal samples were taken on d 28 of each period. Data were analyzed using Proc Mixed of SAS (SAS Institute Inc., Cary, NC). Diet affected dry matter intake, with greatest intake on diet 6 and lowest intake on diets 1 and 3. The highest milk fat content was observed on diet 5 and the greatest fat yield on diet 7; fat content and yield were lowest on diet 1 (soybean meal control). Milk fat secretion was proportional to dietary fat content, indicating that cottonseed oil was used effectively for milk fat synthesis. We observed a trend for an effect on milk protein yield with the greatest protein secretion occurring on diet 7. Milk urea was lowest on diets 3,7 , and 8 . Ruminal concentrations of branched-chain volatile fatty acids were lower, or tended to be lower, when PCSC replaced either UCS or PCS in the diet, suggesting reduced degradation and increased escape of PCSC protein. Among cottonseedcontaining diets, total gossypol intake was lowest on PCSC, intermediate on PCS, and highest on UCS. Total gossypol and both (+)- and (-)-isomers of gossypol were higher in blood plasma on PCS and lower on PCSC than on the corresponding diets containing UCS, indicating that the extrusion process reduced gossypol absorption. In this trial, production on diets supplemented with UCS, PCS, or PCSC was comparable to that on diets containing soybean meal.

Key words: upland cottonseed, Pima cottonseed, extrusion, milk production

\section{INTRODUCTION}

Although still accounting for only 5.5\% of total US ginnings, production of Pima cotton (Gossypium barbadense) increased by $69 \%$ in 2011 over 2010 compared with a $16 \%$ decline for upland cotton (Gossypium hirsutum; USDA-NASS, 2011). This greater production increased the supply of Pima cottonseed, which contains greater concentrations of $\mathrm{CP}$ and oil, but also generally higher concentrations of the antinutritive pigment gos- 
sypol, than upland cottonseed (Sullivan et al., 1993). Elevated gossypol concentration lowers the commercial value of Pima cottonseed, but biofuel production from Pima cottonseed oil would improve the economics of Pima cotton production. However, Pima cottonseed is often fed directly to livestock without removal of oil. One of the authors (T. M. K.) developed an extrusion process that removes 70 to $75 \%$ of the oil from cottonseed. The heat generated in this process could reduce total and free gossypol content, which would decrease gossypol absorption (Mena et al., 2001) and improve protein utilization by increasing the ruminal escape of cottonseed protein (Pena et al., 1986). Craig and Broderick (1981) found that optimal heating of cold-extracted cottonseed meal increased intestinally digestible RUP substantially more than it reduced nutritionally available Lys, thus increasing overall supply of MP and metabolizable Lys.

In commercial practice, cottonseed is fed to dairy cows to provide effective fiber as well as energy and protein and is used to replace a portion of other $\mathrm{CP}$ sources in the diet (Coppock et al., 1987). Cottonseed protein is lower in Lys, but higher in Met and total sulfur-AA (Met plus Cys) than soybean meal (SBM), thus making the 2 proteins complementary in AA pattern (NRC, 2001). Replacing 50\% of RUP from SBM with RUP from cottonseed would reduce ratios of Lys:Met and Lys:(Met plus Cys) in supplemental protein from 4.4 and 2.1 to, respectively, 3.5 and 1.7, based on AA compositions reported in NRC (2001) tables. Cottonseed protein also is higher in His and Arg than soybean protein (NRC, 2001). Limited His content in microbial protein formed in the rumen may make this essential AA critical in circumstances where there is little RUP and microbial protein supplies nearly all of the MP (Vanhatalo et al., 1999).

Therefore, the objectives of this experiment were to determine whether (1) upland or Pima cottonseed could replace $50 \%$ of the CP from supplemental soybean meal; (2) extrusion of Pima cottonseed using a proprietary process to remove oil and heat-treat the protein would reduce blood gossypol concentrations when the extruded cake is fed to dairy cattle; and (3) feeding any of these 3 cottonseed sources to supplement soybean meal would improve milk production.

\section{MATERIALS AND METHODS}

\section{Cottonseed Supplements}

Conventional upland cottonseed (UCS) and Pima cottonseed (PCS) were obtained from Mesa Farmers Cooperative Gin (Vado, NM). About 6,000 kg of Pima cottonseed was processed using a modified Conex 5500
Extruder (Continental Agra Equipment, Newton, KS). This proprietary process heat-treated the PCS and removed $73 \%$ of the oil, exiting the extruder in the form of a Pima cottonseed cake (PCSC). Nine large containers totaling about $5,000 \mathrm{~kg}$ of each cottonseed material were shipped to the US Dairy Forage Center Research Farm in Prairie du Sac, Wisconsin. Two samples, taken from each container, were analyzed for total N (Leco 2000, Leco Instruments Inc., St. Joseph, MI) and for DM after $24 \mathrm{~h}$ at $105^{\circ} \mathrm{C}(\operatorname{method} 967.03$; AOAC, 1990) and results were used in formulating diets. Before mixing into the TMR, the PCS was cracked by rolling through a roller mill (Buffalo KwikKracker, Henke Farm Equipment, Norfolk, NE) with rollers set at 1.0 to $2.0 \mathrm{~mm}$. The PCSC was processed through the same machine except with rollers set at about $2.5 \mathrm{~mm}$. Mean compositions of the 3 cottonseed sources, based on analysis of samples collected during wk 3 and 4 of each period during the lactation trial, are reported in Table 1.

Thirty-two multiparous Holstein cows, 8 of which were fitted with permanent $10-\mathrm{cm}$ ruminal cannulas (Bar Diamond Inc., Parma, ID) with mean (SD) 2.6 (0.9) parity, 91 (69) DIM, 46 (8) $\mathrm{kg}$ of milk/d, and 616 (70) $\mathrm{kg}$ of BW, plus 8 primiparous cows with mean (SD) 101 (50) DIM, 37 (4) kg of milk/d, and 510 (46) kg of BW were used in the trial. Cows were grouped into five $8 \times$ 8 Latin squares to give 1 square of primiparous cows, 1 square of cannulated cows, and 3 squares of multiparous cows blocked by DIM. Cows were randomly assigned within squares to 1 of 5 dietary treatment sequences as described in the Statistical Analysis section. Diets were fed as TMR and contained alfalfa silage, corn silage, and high-moisture corn, solvent-extracted soybean meal (SSBM) or expeller soybean meal (ESBM; SoyPlus, West Central Coop, Ralston, IA), plus 1 or 2 different cottonseeds. Compositions of the other major feed ingredients are in Table 2. Thus, supplemental CP was provided from 8 sources: (1) all from SSBM, or $50 \%$ from SSBM plus 50\% from (2) UCS, (3) PCS, or (4) PCSC; $50 \%$ from SSBM plus $25 \%$ from each of (5) UCS and PCS, or (6) UCS and PCSC; or $50 \%$ from ESBM plus $50 \%$ from (7) PCS or (8) PCSC. These combinations of supplements provided between 31 and $33 \%$ of total dietary CP. Composition of experimental diets actually fed during the trial (based on daily mean weights and weekly mean DM contents of each ingredient mixed in the TMR) are in Table 3. All cows were injected every other week with bST (500 mg of Posilac, Monsanto, St. Louis, MO) beginning about 60 DIM; injections were synchronized such that animals received a full dose on d 1, followed by subsequent bST doses at 14-d intervals throughout the trial. Cows were housed in tie stalls and had free access to water. The Animal Care 
Table 1. Composition of cottonseed supplements ${ }^{1}$

\begin{tabular}{|c|c|c|c|c|c|c|}
\hline \multirow[b]{2}{*}{ Component } & \multicolumn{2}{|c|}{ UCS } & \multicolumn{2}{|c|}{ PCS } & \multicolumn{2}{|c|}{ PCSC } \\
\hline & Mean & SEM & Mean & SEM & Mean & SEM \\
\hline DM, \% & 93.4 & 0.5 & 93.6 & 0.3 & 94.9 & 0.1 \\
\hline $\mathrm{CP}, \%$ of $\mathrm{DM}$ & 20.2 & 1.3 & 21.5 & 0.1 & 27.7 & 0.2 \\
\hline $\mathrm{OM}, \%$ of DM & 95.9 & 0.1 & 95.2 & 0.1 & 94.1 & 0.1 \\
\hline Ether extract, \% of DM & 21.2 & 2.4 & 23.0 & 0.3 & 6.2 & 0.2 \\
\hline $\mathrm{NDF}, \%$ of DM & 48.8 & 1.3 & 44.6 & 0.5 & 46.6 & 0.7 \\
\hline $\mathrm{ADF}, \%$ of $\mathrm{DM}$ & 32.0 & 1.1 & 27.6 & 0.3 & 31.6 & 0.3 \\
\hline Total gossypol, $\mu \mathrm{g} / \mathrm{g}$ of DM & 8.75 & 1.26 & 8.83 & 0.16 & 6.55 & 0.23 \\
\hline$(+)$-Gossypol, $\mu \mathrm{g} / \mathrm{g}$ of DM & 5.05 & 0.72 & 4.09 & 0.08 & 3.05 & 0.11 \\
\hline (+)-Gossypol, \% of total & 57.7 & $<0.1$ & 46.3 & 0.1 & 46.6 & 0.7 \\
\hline (-)-Gossypol, $\mu \mathrm{g} /$ gof DM & 3.71 & 0.53 & 4.74 & 0.08 & 3.50 & 0.12 \\
\hline (-)-Gossypol, \% of total & 42.4 & $<0.1$ & 53.6 & 0.1 & 53.5 & 0.1 \\
\hline NDIN, $\%$ of DM & 11.4 & 1.0 & 12.1 & 0.3 & 9.7 & 0.4 \\
\hline ADIN, $\%$ of DM & 7.2 & 0.5 & 7.5 & 0.3 & 6.9 & 0.2 \\
\hline $\mathrm{B} 3,{ }^{2} \%$ of total $\mathrm{N}$ & 4.2 & 0.7 & 4.6 & 0.6 & 2.8 & 0.3 \\
\hline
\end{tabular}

and Use Committee of the College of Agricultural and Life Sciences of the University of Wisconsin-Madison approved all procedures involving the animals.

Each of the 4 experimental periods lasted $28 \mathrm{~d}$ and consisted of $14 \mathrm{~d}$ for adaptation after diet reversal and $14 \mathrm{~d}$ for collection of intake and production data. Diets were offered once daily at $1000 \mathrm{~h}$; orts were collected and weights recorded at $0900 \mathrm{~h}$. Feeding rate was adjusted daily to yield orts equivalent to about 5 to $10 \%$ of intake. The mean refusal rate observed over the trial was $8.1 \%$ of feed DM offered. Weekly composites of alfalfa silage, corn silage, high-moisture shelled corn, and the 8 different TMR and orts, were obtained from daily subsamples of about $0.5 \mathrm{~kg}$ of each material that were stored at $-20^{\circ} \mathrm{C}$. Weekly samples of soyhulls, SSBM, ESBM, UCS, PCS, and PCSC were also collected and stored at room temperature. Dry matter was determined in weekly composites of corn silage, alfalfa silage, and high-moisture shelled corn by drying at $60^{\circ} \mathrm{C}$ for $48 \mathrm{~h}$ and in weekly samples of soyhulls, SSBM, ESBM, UCS, PCS, and PCSC by drying for $24 \mathrm{~h}$ at $105^{\circ} \mathrm{C}$ (method 967.03; AOAC, 1990). These DM contents were used to adjust DM composition of TMR over the trial. Intake of $\mathrm{DM}$ was computed based on $60^{\circ} \mathrm{C} \mathrm{DM}$ determinations of weekly composites of TMR and orts. Dried $\left(60^{\circ} \mathrm{C}\right)$ samples of corn silage, alfalfa silage and high-moisture shelled corn and undried samples of soyhulls, SSBM, ESBM, UCS, PCS and PCSC from wk 3 and 4 of each period ( 8 samples of each ingredient over the trial) were ground to pass a 1-mm screen (Wiley mill, Arthur H. Thomas, Philadelphia, PA). These were analyzed for total N, DM (method 967.03; AOAC, 1990), ash and

Table 2. Composition of principal dietary ingredients ${ }^{1}$

\begin{tabular}{|c|c|c|c|c|c|c|c|c|c|c|}
\hline Component & \multicolumn{2}{|c|}{ Alfalfa silage } & \multicolumn{2}{|c|}{ Corn silage } & \multicolumn{2}{|c|}{ HMSC } & \multicolumn{2}{|c|}{ SSBM } & \multicolumn{2}{|c|}{ ESBM } \\
\hline DM, $\%$ & 42.1 & 4.3 & 31.4 & 0.8 & 73.6 & 0.9 & 90.0 & 0.4 & 91.5 & 0.8 \\
\hline $\mathrm{OM}, \%$ of $\mathrm{DM}$ & 90.2 & 0.8 & 95.8 & 0.3 & 98.6 & 0.2 & 92.5 & 0.4 & 93.2 & 0.3 \\
\hline $\mathrm{NDF}, \%$ of DM & 41.3 & 2.3 & 37.9 & 3.9 & 7.9 & 0.7 & 8.1 & 0.7 & 25.3 & 0.6 \\
\hline $\mathrm{ADF}, \%$ of $\mathrm{DM}$ & 31.8 & 2.2 & 20.2 & 2.2 & 1.9 & 0.1 & 4.8 & 0.4 & 8.0 & 0.5 \\
\hline NPN, $\%$ of total $\mathrm{N}$ & 49.5 & 9.25 & 69.1 & 16.0 & - & - & - & - & - & - \\
\hline $\mathrm{NH}_{3}, \%$ of total $\mathrm{N}$ & 1.94 & 0.32 & 4.39 & 1.55 & - & - & - & - & - & - \\
\hline Total AA-N ${ }^{3} \%$ of total $\mathrm{N}$ & 22.0 & 3.3 & 18.4 & 5.4 & - & - & - & - & - & - \\
\hline $\mathrm{pH}$ & 4.48 & 0.08 & 4.26 & 1.09 & - & - & - & - & - & - \\
\hline
\end{tabular}

${ }^{1} \mathrm{HMSC}=$ high-moisture shelled corn, SSBM $=$ solvent soybean meal, ESBM = expeller soybean meal (SoyPlus, West Central Coop, Ralston, IA).

${ }^{2} \mathrm{~B} 3=\mathrm{NDIN}-\mathrm{ADIN}$.

${ }^{3}$ Computed assuming $40.3 \mu \mathrm{mol}$ of total free $\mathrm{AA} / \mathrm{mg}$ of $\mathrm{N}$ in alfalfa and corn silage (Broderick, 1987). 
Table 3. Composition (\% of DM unless otherwise noted) of experimental diets

\begin{tabular}{|c|c|c|c|c|c|c|c|c|}
\hline Item & \multicolumn{8}{|c|}{ Supplemental protein ${ }^{1}$} \\
\hline Alfalfa silage & 29.9 & 29.8 & 29.9 & 30.0 & 29.8 & 29.9 & 29.8 & 30.0 \\
\hline Corn silage & 30.8 & 30.7 & 30.8 & 30.9 & 30.7 & 30.8 & 30.7 & 30.9 \\
\hline High-moisture shelled corn & 25.3 & 20.5 & 21.3 & 24.1 & 21.1 & 22.4 & 20.9 & 23.3 \\
\hline Pima cottonseed $^{2}$ & 0 & 0 & 10.8 & 0 & 5.3 & 0 & 10.7 & 0 \\
\hline Pima cottonseed cake ${ }^{3}$ & 0 & 0 & 0 & 7.9 & 0 & 3.9 & 0 & 7.9 \\
\hline Soyhulls & 4.6 & 0 & 0 & 0 & 0 & 0 & 0 & 0 \\
\hline Calcium sulfate & 1.42 & 1.42 & 1.42 & 1.42 & 1.42 & 1.42 & 1.42 & 1.42 \\
\hline Biophos & 0.23 & 0.23 & 0.23 & 0.23 & 0.23 & 0.23 & 0.23 & 0.23 \\
\hline Sodium chloride & 0.2 & 0.2 & 0.2 & 0.2 & 0.2 & 0.2 & 0.2 & 0.2 \\
\hline Cottonseed CP, $\%$ of total & 0 & 17 & 16 & 15 & 16 & 16 & 16 & 15 \\
\hline Ash & 5.6 & 5.6 & 5.6 & 5.6 & 5.6 & 5.6 & 5.6 & 5.5 \\
\hline $\mathrm{NDF}$ & 27.3 & 30.5 & 29.7 & 28.7 & 30.0 & 29.5 & 30.1 & 29.2 \\
\hline Fat & 3.0 & 5.1 & 5.2 & 3.3 & 5.1 & 4.2 & 5.4 & 3.5 \\
\hline NFC & 1.5 & 1.6 & 1.6 & 1.8 & 1.6 & 1.7 & 2.0 & 2.3 \\
\hline Total gossypol, $\mathrm{g} / \mathrm{kg}$ of DM & 0 & 1.04 & 0.95 & 0.52 & 0.98 & 0.77 & 0.94 & 0.52 \\
\hline $\mathrm{NE}_{\mathrm{L}},{ }^{5} \mathrm{Mcal} / \mathrm{kg}$ of DM & 1.50 & 1.55 & 1.56 & 1.50 & 1.55 & 1.52 & 1.57 & 1.50 \\
\hline $\mathrm{NE}_{\mathrm{L}}$-allowable milk ${ }_{2}^{5} \mathrm{~kg} / \mathrm{d}$ & 42 & 44 & 44 & 42 & 44 & 43 & 45 & 42 \\
\hline MP-allowable milk, ${ }^{5} \mathrm{~kg} / \mathrm{d}$ & 36 & 33 & 34 & 33 & 33 & 33 & 37 & 37 \\
\hline $\mathrm{MP}^{5} \mathrm{~g} / \mathrm{d}$ & 2,506 & 2,407 & 2,421 & 2,397 & 2,411 & 2,399 & 2,588 & 2,567 \\
\hline Lys:Met ratio in $\mathrm{MP}^{5}$ & 3.6 & 3.5 & 3.5 & 3.5 & 3.5 & 3.5 & 3.6 & 3.5 \\
\hline
\end{tabular}

${ }^{1}$ Sources of supplemental CP: SSBM $=$ solvent soybean meal, ESBM $=$ expeller soybean meal (SoyPlus, West Central Coop, Ralston, IA), UCS $=$ upland cottonseed, PCS $=$ Pima cottonseed, PCSC $=$ Pima cottonseed cake (extruded).

${ }^{2}$ Pima cottonseed was cracked by rolling before incorporation into the TMR.

${ }^{3}$ Pima cottonseed cake, prepared by experimental extrusion process, was rolled to reduce mean particle size before incorporation into the TMR. ${ }^{4}$ Provided (per kilogram of DM) $56 \mathrm{mg}$ of $\mathrm{Zn}, 46 \mathrm{mg}$ of $\mathrm{Mn}, 22 \mathrm{mg}$ of Fe, $12 \mathrm{mg}$ of Cu, $0.9 \mathrm{mg}$ of I, $0.4 \mathrm{mg}$ of Co, $0.3 \mathrm{mg}$ of Se, 6,440 IU of vitamin A, 2,000 IU of vitamin D, 16 IU of vitamin E, and $12 \mathrm{mg}$ of monensin.

${ }^{5}$ Computed according to NRC (2001) model using mean observed DMI $(26.3 \mathrm{~kg} / \mathrm{d})$ and measured fat contents of cottonseed materials, and assuming that the MP contribution from CP in PCS and PCSC was the same as that from UCS. This computation assumed no effect of gossypol on bioavailability of Lys.

OM (AOAC, 1980), sequentially for NDF, ADF, and ADIN using heat stable $\alpha$-amylase and $\mathrm{Na}_{2} \mathrm{SO}_{3}$ (Van Soest et al., 1991; Hintz et al., 1996), and for NDIN omitting $\alpha$-amylase and $\mathrm{Na}_{2} \mathrm{SO}_{3}$ during extraction (Licitra et al., 1996). The TMR samples collected during wk 4 of each period were also were analyzed for indigestible ADF (ADF remaining after $288 \mathrm{~h}$ of in situ incubation) by the method of Huhtanen et al. (1994). The 8 samples each of UCS, PCS, and PCSC were analyzed for total lipids according to AOAC International (1997; method 920.39; Dairyland Laboratories, Arcadia, WI) and for gossypol [total gossypol, (+)-gossypol, and (-)-gossypol] by methods based on AOCS Recommended Practice Ba 8a-99 (AOCS, 1998) as modified by Pettigrew and Dowd (2011). Frozen composites of alfalfa and corn silages were thawed and analyzed for NPN (Muck, 1987; Leco FP-2000 N Analyzer).
Cows were milked twice daily at 0500 and $1700 \mathrm{~h}$, and milk yield was recorded at each milking in all experimental periods. Milk samples from a.m. and p.m. milkings were collected on d 17 to 18 and 24 to 25 of each period and analyzed for fat, true protein, lactose, and SNF by infrared analysis (AgSource, Verona, WI) with a Foss FT6000 (Foss North America Inc., Eden Prairie, MN) using AOAC (1990; method 972.16). For MUN determination, $5 \mathrm{~mL}$ of milk from each milking was treated with $5 \mathrm{~mL}$ of $25 \%$ (wt/vol) TCA. Samples were vortexed and allowed to stand for $30 \mathrm{~min}$ at room temperature $\left(22-24^{\circ} \mathrm{C}\right)$ before filtering through Whatman \#1 filter paper. Filtrates were stored at $-20^{\circ} \mathrm{C}$ until MUN analysis by an automated colorimetric assay (Broderick and Clayton, 1997) adapted to flow-injection (Lachat Quik-Chem 8000 FIA, Lachat Instruments, Milwaukee, WI). Concentrations and yields of fat, true 
protein, lactose, and SNF and concentration of MUN were computed as weighted means based on a.m. and p.m. milk yields on each test-day. Yields of 3.5\% FCM (Sklan et al., 1992) and ECM (Krause and Combs, 2003) were also computed. Efficiency of conversion of feed DM was calculated for each cow over the last $2 \mathrm{wk}$ of each period by dividing mean yield of actual milk, and of FCM and ECM, by mean DMI. Apparent N efficiency (assuming no retention or mobilization of body $\mathrm{N}$ ) was computed for each cow by dividing the period mean for milk $\mathrm{N}$ secretion (milk true protein/6.38) by mean $\mathrm{N}$ intake. For computation of BW change, BW was measured on 3 consecutive days at the beginning of the experiment and at the end of each period.

On d 28 of each period, blood samples were collected from a coccygeal vessel into evacuated heparinized tubes at approximately $4 \mathrm{~h}$ postfeeding and placed on ice until transported to the laboratory. Blood was centrifuged $\left(1,160 \times g, 15 \mathrm{~min}, 4^{\circ} \mathrm{C}\right)$ and the resulting plasma was stored at $-20^{\circ} \mathrm{C}$ until analyzed for total gossypol, (+)-gossypol, and (-)-gossypol as described for cottonseed samples except scaled to the lower concentrations found in plasma as described by Bullock et al. (2010). Spot urine and fecal samples were also collected on d 28 of each period at $6 \mathrm{~h}$ before and $6 \mathrm{~h}$ after feeding. Urine was immediately diluted by mixing $15 \mathrm{~mL}$ of each sample with $60 \mathrm{~mL}$ of $0.072 \mathrm{~N} \mathrm{H}_{2} \mathrm{SO}_{4}$ and storing at $-20^{\circ} \mathrm{C}$ until analysis. Fecal samples were dried for $72 \mathrm{~h}$ at $60^{\circ} \mathrm{C}$, ground through a $1-\mathrm{mm}$ screen (Wiley mill), and composited on an equal DM basis to obtain 1 fecal sample/cow per period. All fecal samples were analyzed for DM, ash, OM, NDF, ADF, total N, and indigestible ADF using the assays described above. Indigestible ADF was used as an internal marker to estimate apparent nutrient digestibility and fecal output based on computations used by Cochran et al. (1986). Urine samples were thawed and analyzed for total $\mathrm{N}$ by elemental analysis (Leco FP-2000 N Analyzer), for urea using the colorimetric assay used for MUN, and for creatinine (Valadares et al., 1999). Daily urine volume and excretion of urea $\mathrm{N}$ and total $\mathrm{N}$ were estimated from mean urinary concentrations in each period assuming a creatinine excretion rate of $29 \mathrm{mg} / \mathrm{kg}$ of BW (Valadares et al., 1999).

On d 27 to 28 of each period, about 100 to $200 \mathrm{~mL}$ of fluid digesta was collected from 4 locations in the ventral rumen at 0 (just before feeding), 1, 2, 4, 6, $8,12,18$, and $24 \mathrm{~h}$ after feeding from the 8 lactating Holstein cows fitted with ruminal cannulas using the probe described by Olmos Colmenero and Broderick (2006). At each sampling, mixed fluid digesta was strained through 2 layers of cheesecloth and $\mathrm{pH}$ measured immediately in strained fluid using a glass electrode. Two 10-mL aliquots of ruminal fluid were then preserved in scintillation vials by addition of 0.2 $\mathrm{mL}$ of $50 \% \mathrm{H}_{2} \mathrm{SO}_{4}$ and stored at $-20^{\circ} \mathrm{C}$. The remaining fluid and digesta were returned to the rumen. Just before analysis, samples were thawed and centrifuged $\left(15,300 \times g\right.$ for 20 min at $\left.4^{\circ} \mathrm{C}\right)$ and flow-injection analyses (Lachat QuikChem 8000) applied to supernatants to determine ammonia, using a phenol-hypochlorite method (Lachat method 18-107-06-1-A), and total AA using a fluorimetric procedure based on the reaction with o-phthaldialdehyde (Roth, 1971). Leucine was the standard in the $o$-phthaldialdehyde assay and total AA values were reported in Leu equivalents. Samples were also thawed and centrifuged $(28,000 \times g$ for $30 \mathrm{~min}$ at $4^{\circ} \mathrm{C}$ ) before VFA determination using a modification of the gas-liquid chromatography method for free fatty acids described in Supelco Bulletin 855B (Supelco Inc., Supelco Park, Bellefonte, PA) with flame-ionization detection. Standards or supernatants $(0.5$ or $1 \mu \mathrm{L})$ were injected onto a ZB-FFAP capillary column $(30 \mathrm{~m} \times$ $0.53 \mathrm{~mm} \times 1.0 \mu \mathrm{m}$; 7HK-G009-22; Phenomenex Inc., Torrance, CA) with helium carrier gas at $100 \mathrm{kPa}$ and a flow rate of $20 \mathrm{~mL} / \mathrm{min}$. Column oven temperature was $100^{\circ} \mathrm{C}$ at injection; after $2 \mathrm{~min}$, temperature was increased to $130^{\circ} \mathrm{C}$ at $10^{\circ} \mathrm{C} / \mathrm{min}$. Injector and detector temperatures were $230^{\circ} \mathrm{C}$ and $250^{\circ} \mathrm{C}$. The method did not resolve isovalerate and 2-methyl butyrate.

\section{Statistical Analysis}

The lactation trial was conducted as an incomplete $8 \times 8$ Latin square, replicated 5 times. It was intended from the outset to run the trial for 4 periods only, rather than for the full 8 periods, to avoid confounding effects due to the decline in production that would have occurred later in the lactation curve. Five incomplete $8 \times 8$ Latin squares were constructed by fixing the first column of treatments, ordered A through $\mathrm{H}$, as the diets fed in period 1 , and then randomly assigning 3 of 7 possible columns of treatments (ordered $\mathrm{B}, \mathrm{C}, \ldots, \mathrm{A}$; $\mathrm{C}, \mathrm{D}, \ldots, \mathrm{B} ; \ldots ; \mathrm{H}, \mathrm{A}, \ldots, \mathrm{G})$ as the subsequent series of diets in periods 2,3 , and 4 . With this arrangement, columns represented periods and rows represented cows within squares. The 5 groups of cows, blocked as described above, were randomly assigned to 1 of these 5 incomplete $8 \times 8$ Latin squares. Within squares, cows were randomly assigned to 1 of the 8 diet sequences. Equal numbers of observations were made on all traits for each dietary treatment. Results from the lactation trial were analyzed using the mixed procedures of SAS Institute (1999-2000) for replicated Latin squares. The following model was used to fit production data to assess effects of dietary treatments: 


$$
\mathrm{Y}_{\mathrm{ijkl}}=\mu+\mathrm{S}_{\mathrm{i}}+\mathrm{P}_{\mathrm{j}}+\mathrm{C}_{\mathrm{k}(\mathrm{i})}+\mathrm{T}_{1}+\mathrm{ST}_{\mathrm{il}}+\mathrm{E}_{\mathrm{ijkl}},
$$

where $Y_{\mathrm{ijk} l}=$ dependent variable, $\mu=$ overall mean, $\mathrm{S}_{\mathrm{i}}$ $=$ effect of square $\mathrm{i}, \mathrm{P}_{\mathrm{j}}=$ effect of period $\mathrm{j}, \mathrm{C}_{\mathrm{k}(\mathrm{i})}=$ effect of cow $\mathrm{k}$ (within square i), $\mathrm{T}_{1}=$ effect of dietary treatment $1, \mathrm{ST}_{\mathrm{il}}=$ interaction of square $\mathrm{i}$ and treatment $\mathrm{l}$, and $\mathrm{E}_{\mathrm{ijkl}}=$ residual error. All terms were considered fixed, except for $\mathrm{C}_{\mathrm{k}(\mathrm{i})}$ and $\mathrm{E}_{\mathrm{ijkl}}$, which were considered random.

The following model was used for ruminal variables for which there were repeated measurements over time ( $\mathrm{pH}$, ammonia, total free $\mathrm{AA}$, and individual and total VFA):

$$
\mathrm{Y}_{\mathrm{ijkl}}=\mu+\mathrm{P}_{\mathrm{i}}+\mathrm{C}_{\mathrm{j}}+\mathrm{T}_{\mathrm{k}}+\mathrm{E}_{\mathrm{ijk}}+\mathrm{Z}_{\mathrm{l}}+\mathrm{ZT}_{\mathrm{lk}}+\omega_{\mathrm{ijk} \mathrm{l}},
$$

where $Y_{\mathrm{ijkl}}=$ dependent variable, $\mu=$ overall mean, $\mathrm{P}_{\mathrm{i}}$ $=$ effect of period $\mathrm{i}, \mathrm{C}_{\mathrm{j}}=$ effect of cow $\mathrm{j}, \mathrm{T}_{\mathrm{k}}=$ effect of dietary treatment $\mathrm{k}, \mathrm{E}_{\mathrm{ijk}}=$ whole plot error, $\mathrm{Z}_{\mathrm{l}}=$ effect of time $\mathrm{l}, \mathrm{ZT}_{\mathrm{lk}}=$ interaction of time $\mathrm{l}$ and treatment $\mathrm{k}$, and $\omega_{\mathrm{ijk}}=$ subplot error. The spatial covariance structure $\mathrm{SP}(\mathrm{POW})$ was used for estimating covariance and the subject of the repeated measurements was defined as cow(period $\times$ treatment). All terms were considered fixed, except for $\mathrm{C}_{\mathrm{j}}, \mathrm{E}_{\mathrm{ijk}}$, and $\omega_{\mathrm{ijkl}}$, which were considered random. Differences between least squares means are reported only if the $F$-test for dietary treatment was significant at $\alpha=0.05$. Trends were declared at $0.05<P \leq 0.10$.

\section{RESULTS AND DISCUSSION}

\section{Feed Quality and Diet Composition}

Composition data of the 3 cottonseed sources fed in the trial are in Table 1 . As is typically observed (Sullivan et al., 1993; Santos et al., 2002;2005), PCS contained higher concentrations of $\mathrm{CP}$ and lipid and lower concentrations of NDF and ADF compared with UCS. However, the high-speed ginning process used to produce the PCS left more fiber in that material than was reported previously, which diluted the $\mathrm{CP}$ and ether extract. Sullivan et al. (1993) observed 6.1 and 3.1 percentage units more $\mathrm{CP}$ and ether extract, respectively, in PCS than UCS, whereas Santos et al. (2002) found 4.5 and 2.4 percentage units more CP and ether extract in PCS than UCS. The PCS and UCS fed in this trial had similar contents of total gossypol, which was unexpected. Although most reports indicated that Pima cottonseed has greater total gossypol than upland cottonseed (Sullivan et al., 1993; McCaughey et al., 2005; Santos et al., 2005), others have observed gossypol concentrations in some Pima cultivars that were similar to those of upland cottonseed (Scheffler and Romano, 2008). In the current study, cottonseeds contained different proportions of the 2 gossypol isomers: UCS contained $57.7 \%(+)$-gossypol, whereas PCS contained $53.6 \%$ (-)-gossypol. The experimental extrusion process reduced lipid content by $73 \%$ and total gossypol by $26 \%$ in PCSC compared with that present in the PCS starting material. Heat treatment of cottonseed products promotes reaction of free gossypol with Lys residues in cottonseed protein (Craig and Broderick, 1981), a process that may reduce gossypol absorption (Santos et al., 2005). Distribution of the gossypol isomers was the same in PCSC as in PCS. Despite the extrusion step, which presumably promoted reaction of gossypol with protein in PCSC, this material contained a lower proportion of total $\mathrm{N}$ as NDIN. Heating of proteins generally increases NDIN concentration and proportion of total N (e.g., Coblentz et al., 2010).

Contents of DM, CP, NDF, and ADF in alfalfa silage, corn silage, high-moisture corn, and the 2 soybean meals (Table 2) indicated that these feedstuffs were of typical composition (NRC, 2001). The NPN in alfalfa silage was about $50 \%$ of total N; NPN normally accounts for 45 to $55 \%$ of total $\mathrm{N}$ in alfalfa silage (Broderick, 1995). Very low contents of ammonia- $\mathrm{N}$ in both alfalfa and corn silages indicated that these feeds were well preserved (McDonald et al., 1991). The 8 diets ranged from (DM basis) 27.3 to $30.5 \%$ NDF, 1.50 to 1.56 estimated Mcal of $\mathrm{NE}_{\mathrm{L}} / \mathrm{kg}$ (computed at $3 \times$ maintenance; $\mathrm{NRC}, 2001$ ), and 3.0 to $5.2 \%$ total fat (Table 3). Supplemental soybean meal plus cottonseed ingredients supplied between 31 and $33 \%$ of total dietary CP; cottonseed from UCS, PCS, or PCSC provided about $50 \%$ of this CP in the 7 experimental diets to which they were added. Replacement of soybean meal CP with CP from UCS and PCS increased NDF, total fat, and, because of the added fat, estimated Mcal of $\mathrm{NE}_{\mathrm{L}} / \mathrm{kg}$ (NRC, 2001); substitution of all or half of either of these cottonseed CP sources with PCSC decreased NDF and fat to concentrations similar to that of the SSBM control diet (Table 3). Based on NRC (2001) computations at the overall mean DMI $(26.3 \mathrm{~kg} / \mathrm{d})$, MP-allowable milk ranged from 33 to 37 $\mathrm{kg} / \mathrm{d}$, whereas $\mathrm{NE}_{\mathrm{L}}$-allowable milk ranged from 42 to $44 \mathrm{~kg} / \mathrm{d}$ (Table 3). Moreover, all diets contained 14.7 to $14.8 \%$ CP; Broderick et al. (2008) found that yield of milk and milk components on a diet with $14.8 \% \mathrm{CP}$ was lower than that on 16.1 and $17.3 \%$ CP. This suggested that MP or AA supplies limited production in the current study. Thus, production differences between the SSBM control diet and the other experimental diets may be attributed to effects on MP supply from replacing SSBM protein with that from other protein sources. 


\section{Animal Responses}

Lactation performance was relatively high in this experiment, with DMI, milk yield, and protein yield averaging, respectively, 26.3, 44.4, and $1.26 \mathrm{~kg} / \mathrm{d}$ (Table 4). Significant effects $(P \leq 0.04)$ of diet were observed on DMI, milk fat content and yield, milk protein content, and MUN concentration. Intake was lowest on the SSBM + PCS diet and greatest on the SSBM + UCS + PCSC diet, with the other treatments falling in between. Replacing SSBM CP with PCSC rather than PCS increased DMI by $1.4 \mathrm{~kg} / \mathrm{d}$, implying that the experimental extrusion process directly affected feed intake. However, extrusion reduced oil content and, thus, dietary $\mathrm{NE}_{\mathrm{L}}$ from 1.54 to $1.50 \mathrm{Mcal} / \mathrm{kg}$ of $\mathrm{DM}$ in the SSBM + PCSC diet (Table 3), suggesting that this difference was due to the lower energy density stimulating intake (NRC, 2001). It was noted that DMI on the SSBM control was similar to that on SSBM + PCS, despite the lower fat and $\mathrm{NE}_{\mathrm{L}}$ in that diet.

Milk fat content and yield were influenced by diet (Table 4), with the greatest fat concentration occurring when cows were fed UCS + PCSC and the greatest fat yield when cows were fed ESBM + PCS; these traits were lowest on the SSBM control diet, with the other treatments being intermediate. Feeding the 2 PCSC diets with fat and $\mathrm{NE}_{\mathrm{L}}$ contents similar to the SSBM control (SSBM + PCSC and SSBM + PCSC) gave rise to milk fat content and yield that were not different from the SSBM control. These results confirm the many observations indicating that cottonseed oil is an effective energy source for lactation with few or no negative effects on milk fat synthesis. In their review, Coppock et al. (1987) summarized data showing that increased milk fat content and yield were the most commonly reported effects when whole cottonseed was fed to lactating cows. Mohamed et al. (1988) observed similar milk and component yields on $16.5 \% \mathrm{CP}$ diets when supplemental protein came from either SSBM or cottonseed meal; however, replacing cottonseed meal with whole cottonseed increased fat and protein yields, whereas replacing SSBM with whole soybeans depressed yields of fat and protein. Mena et al. (2001) fed isonitrogenous diets supplemented with combinations of SSBM, cottonseed meal, and whole UCS and observed that milk fat yields were proportional to dietary fat intake coming from whole cottonseed. We observed trends for an effect of diet on ECM yield but, as expected, the ECM trend followed the pattern of fat yield, with the numerically highest yield on ESBM + PCS and the lowest on SSBM control.

Milk protein content was influenced by diet, being highest on SSBM + PCSC and the SSBM control and lowest on SSBM + UCS + PCS (Table 4). The reduc- tion of milk protein from 2.95 to $2.83 \%$ when ESBM replaced SSBM in the PCSC diet was surprising. Milk protein content is less important than, and often inversely related to, protein yield (NRC, 2001), and trends for protein secretion displayed some interesting differences in this trial. The numerically greatest protein yield occurred on ESBM + PCS, the diet with the numerically highest milk and ECM yields; however, protein yield was numerically lowest on the other 2 diets containing PCS (SSBM + PCS and SSBM + UCS + PCS). This pattern suggested that RUP (from ESBM or possibly PCSC) may have improved protein utilization, but the lesser production on PCSC + ESBM suggested that the combination impaired protein secretion because of inadequate RDP supply. The large number of dietary treatments prevented all cows from receiving all 8 experimental diets in this study, which probably reduced trial sensitivity and may have prevented our detecting the numeric differences as statistically significant. It is noted that each diet followed every other diet 2 or 3 times over the course of the study, which would be expected to balance carryover effects across treatments.

Several researchers have reported high levels of milk production when cottonseed was fed to lactating dairy cows. Mohamed et al. (1988) observed similar milk yield but greater protein yield when dietary CP from soybeans or SSBM was replaced with equal CP from upland cottonseed or cottonseed meal. However, Brito and Broderick (2007) reported similar milk yield and a trend for reduced protein yield when all supplemental CP was fed as cottonseed meal rather than SSBM. Santos et al. (2002) found no difference in most milk production traits but higher milk protein content when cracked Pima cottonseed replaced $69 \%$ of dietary upland cottonseed in a large-scale trial conducted on commercial dairies using early- to mid-lactation cows. Prieto et al. (2003) fed lactating cows diets containing $12.8 \%$ whole cottonseed in which Pima replaced 0, 33, 67 , and $100 \%$ of dietary upland cottonseed and found no effect on yield of milk and milk components until the diet contained $12.8 \%$ Pima cottonseed, at which point DMI was reduced.

Altered MUN was also observed in this trial, with concentrations being lowest on SSBM + PCS and the 2 diets containing ESBM, highest on SSBM + UCS + PCSC, and intermediate on the other 4 diets (Table 4). However, MUN concentrations were low in this trial, $<10 \mathrm{mg} / \mathrm{dL}$ on all treatments, reflecting the relatively low CP diets that were fed (Nousiainen et al., 2004) and the relatively high N-efficiencies (milk-N:N-intake) observed in this trial (Broderick and Clayton, 1997). These results indicated that MP utilization was efficient and implied that this MP had an effective AA pattern. Estimates of the Lys:Met ratio in MP made using the 
Table 4. Effects of source of supplemental protein on intake and production and on concentrations of gossypol isomers in blood plasma ${ }^{1}$

\begin{tabular}{|c|c|c|c|c|c|c|c|c|c|c|}
\hline \multirow[b]{2}{*}{ Item } & \multicolumn{8}{|c|}{ Supplemental protein } & \multirow[b]{2}{*}{$\mathrm{SE}$} & \multirow[b]{2}{*}{$\begin{array}{l}\text { Diet }^{2} \\
P>\mathrm{F}\end{array}$} \\
\hline & SSBM & $\underset{\text { UCS }}{\mathrm{SSBM}}+$ & $\begin{array}{c}\text { SSBM }+ \\
\text { PCS }\end{array}$ & $\begin{array}{c}\mathrm{SSBM}+ \\
\mathrm{PCSC}\end{array}$ & $\begin{array}{c}\text { SSBM + } \\
\text { UCS + PCS }\end{array}$ & $\begin{array}{c}\text { SSBM }+ \\
\text { UCS + PCSC }\end{array}$ & $\begin{array}{c}\mathrm{ESBM}+ \\
\mathrm{PCS}\end{array}$ & $\begin{array}{l}\mathrm{ESBM}+ \\
\mathrm{PCSC}\end{array}$ & & \\
\hline $\mathrm{DMI}, \mathrm{kg} / \mathrm{d}$ & $25.7^{\mathrm{de}}$ & $26.3^{\mathrm{bcd}}$ & $25.5^{\mathrm{e}}$ & $26.9^{\mathrm{ab}}$ & $26.0^{\text {cde }}$ & $27.2^{\mathrm{a}}$ & $26.5^{\mathrm{bc}}$ & $26.3^{\mathrm{bcd}}$ & 0.42 & $<0.01$ \\
\hline BW gain, $\mathrm{kg} / \mathrm{d}$ & 0.21 & 0.37 & 0.13 & 0.31 & 0.03 & 0.29 & 0.34 & 0.15 & 0.109 & 0.28 \\
\hline Milk, kg/d & 43.7 & 43.8 & 43.1 & 44.4 & 44.3 & 45.7 & 45.9 & 43.8 & 1.19 & 0.11 \\
\hline Milk/DMI & 1.70 & 1.66 & 1.69 & 1.65 & 1.70 & 1.68 & 1.72 & 1.67 & 0.036 & 0.46 \\
\hline $\mathrm{ECM}, \mathrm{kg} / \mathrm{d}$ & 40.3 & 42.3 & 41.6 & 41.4 & 42.5 & 43.4 & 44.3 & 41.0 & 1.23 & 0.08 \\
\hline ECM/DMI & 1.57 & 1.60 & 1.62 & 1.54 & 1.63 & 1.59 & 1.66 & 1.56 & 0.038 & 0.13 \\
\hline Fat, $\%$ & $3.65^{\mathrm{c}}$ & $3.94^{\mathrm{ab}}$ & $4.03^{\mathrm{a}}$ & $3.75^{\mathrm{bc}}$ & $4.02^{\mathrm{a}}$ & $3.95^{\mathrm{ab}}$ & $3.92^{\mathrm{ab}}$ & $3.76^{\mathrm{bc}}$ & 0.108 & 0.02 \\
\hline Fat, $\mathrm{kg} / \mathrm{d}$ & $1.57^{\mathrm{c}}$ & $1.72^{\mathrm{ab}}$ & $1.72^{\mathrm{ab}}$ & $1.64^{\mathrm{bc}}$ & $1.77^{\mathrm{ab}}$ & $1.77^{\mathrm{ab}}$ & $1.81^{\mathrm{a}}$ & $1.66^{\mathrm{bc}}$ & 0.063 & 0.02 \\
\hline True protein, \% & $2.94^{\mathrm{a}}$ & $2.86^{\mathrm{abc}}$ & $2.87^{\mathrm{abc}}$ & $2.95^{\mathrm{a}}$ & $2.80^{\mathrm{c}}$ & $2.87^{\mathrm{abc}}$ & $2.85^{\mathrm{bc}}$ & $2.83^{\mathrm{c}}$ & 0.048 & 0.04 \\
\hline True protein, kg/d & 1.26 & 1.24 & 1.22 & 1.29 & 1.22 & 1.28 & 1.31 & 1.23 & 0.033 & 0.10 \\
\hline Lactose, $\%$ & 4.97 & 4.97 & 4.95 & 4.93 & 4.94 & 4.97 & 4.94 & 4.87 & 0.053 & 0.78 \\
\hline Lactose, $\mathrm{kg} / \mathrm{d}$ & 2.17 & 2.19 & 2.12 & 2.17 & 2.17 & 2.24 & 2.29 & 2.12 & 0.067 & 0.21 \\
\hline $\mathrm{SNF}, \%$ & 8.73 & 8.68 & 8.67 & 8.75 & 8.59 & 8.70 & 8.66 & 8.53 & 0.081 & 0.43 \\
\hline $\mathrm{SNF}, \mathrm{kg} / \mathrm{d}$ & 3.79 & 3.80 & 3.70 & 3.83 & 3.76 & 3.90 & 3.99 & 3.72 & 0.105 & 0.18 \\
\hline MUN, mg/dL & $9.1^{\mathrm{bc}}$ & $8.9^{\mathrm{cd}}$ & $8.9^{\mathrm{cd}}$ & $9.3^{\mathrm{ab}}$ & $9.1^{\mathrm{bc}}$ & $9.8^{\mathrm{a}}$ & $8.6^{\mathrm{c}}$ & $9.5^{\mathrm{ab}}$ & 0.30 & $<0.01$ \\
\hline Milk-N/N-intake, \% & 32.2 & 31.1 & 31.3 & 32.0 & 31.1 & 31.4 & 32.4 & 31.2 & 0.61 & 0.47 \\
\hline Gossypol intake, $\mathrm{g} / \mathrm{d}$ & $0^{\mathrm{f}}$ & $27.4^{\mathrm{a}}$ & $24.5^{\mathrm{c}}$ & $14.0^{\mathrm{e}}$ & $25.5^{\mathrm{b}}$ & $20.8^{\mathrm{d}}$ & $25.1^{\mathrm{bc}}$ & $13.6^{\mathrm{e}}$ & 0.32 & $<0.01$ \\
\hline Gossypol intake, $\mathrm{mg} / \mathrm{kg}$ of $\mathrm{BW}$ per day & $0^{\mathrm{f}}$ & $44.5^{\mathrm{a}}$ & $40.1^{\mathrm{c}}$ & $22.4^{\mathrm{e}}$ & $42.0^{\mathrm{b}}$ & $33.9^{\mathrm{d}}$ & $40.8^{\mathrm{bc}}$ & $22.1^{\mathrm{e}}$ & 0.76 & $<0.01$ \\
\hline \multicolumn{11}{|l|}{ Blood plasma gossypol } \\
\hline Total gossypol (period 1$){ }^{3} \mu \mathrm{g} / \mathrm{mL}$ & 0.15 & 1.61 & 4.36 & 0.82 & 2.83 & 1.11 & 3.00 & 0.66 & - & - \\
\hline Total gossypol, $\mu \mathrm{g} / \mathrm{mL}$ & $0.45^{\mathrm{e}}$ & $1.40^{\mathrm{c}}$ & $3.26^{\mathrm{a}}$ & $0.79^{\mathrm{d}}$ & $2.48^{\mathrm{b}}$ & $1.32^{\mathrm{c}}$ & $2.75^{\mathrm{b}}$ & $0.74^{\mathrm{d}}$ & 0.106 & $<0.01$ \\
\hline$(-)$-Gossypol, $\mu \mathrm{g} / \mathrm{mL}$ & $0.29^{\mathrm{e}}$ & $0.86^{\mathrm{c}}$ & $2.24^{\mathrm{a}}$ & $0.52^{\mathrm{d}}$ & $1.62^{\mathrm{b}}$ & $0.84^{\mathrm{c}}$ & $1.89^{\mathrm{b}}$ & $0.49^{\mathrm{d}}$ & 0.075 & $<0.01$ \\
\hline (+)-Gossypol, $\mu \mathrm{g} / \mathrm{mL}$ & $0.16^{\mathrm{e}}$ & $0.54^{\mathrm{c}}$ & $1.02^{\mathrm{a}}$ & $0.26^{\mathrm{d}}$ & $0.86^{\mathrm{b}}$ & $0.48^{\mathrm{c}}$ & $0.86^{\mathrm{b}}$ & $0.25^{\mathrm{d}}$ & 0.033 & $<0.01$ \\
\hline (+)-Gossypol/total, \% & $38^{\mathrm{a}}$ & $39^{\mathrm{a}}$ & $32^{\mathrm{c}}$ & $34^{\mathrm{b}}$ & $35^{\mathrm{b}}$ & $37^{\mathrm{a}}$ & $31^{\mathrm{c}}$ & $35^{\mathrm{b}}$ & 1.0 & $<0.01$ \\
\hline
\end{tabular}

${ }^{\mathrm{O}}{ }^{\mathrm{a} e}$ Means within a row with different superscripts differ $(P<0.05)$.

글 $\quad{ }^{1}$ Sources of supplemental CP: SSBM $=$ solvent soybean meal, ESBM $=$ expeller soybean meal (SoyPlus, West Central Coop, Ralston, IA), UCS $=$ upland cottonseed, PCS $=$ cracked Pima cottonseed, PCSC $=$ Pima cottonseed cake (extruded).

离. $\quad$ Probability of a significant effect of diet.

ஸ ${ }^{3}$ Mean total gossypol concentration in blood plasma at the end of period 1 ( 5 cows/treatment). 
NRC (2001) model, which does not discount Lys bioavailability due to gossypol binding, ranged from 3.5 to 3.6 on all diets (Table 3). However, cottonseed protein is low in Lys and was estimated to contribute only 20 to $23 \mathrm{~g} / \mathrm{d}$ of absorbable Lys, assuming $23 \%$ RUP with $80 \%$ intestinal digestibility (NRC, 2001). Ratios of Lys:Met would be reduced to 3.0 to 3.1 if none of the Lys in the cottonseed materials were bioavailable. We expected that replacing SSBM with ESBM would have given measurable improvement in milk and protein yield. Although the ESBM + PCS treatment gave rise to the greatest fat yield as well as numerically highest yields of milk, ECM, and protein, production was lower on ESBM + PCSC despite similar DMI. Applying NRC (2001) assumptions to estimate Met supply suggested that absorbable Met was increased only from 46 to $48 \mathrm{~g} / \mathrm{d}$ when ESBM replaced SSBM in the diets containing PCS and PCSC. If absorbable Met were the limiting nutrient, then the extra $2 \mathrm{~g} / \mathrm{d}$ of Met supply may have been too small to produce consistent differences in production.

We observed large, significant effects observed for concentrations of total gossypol, and (+)- and (-)-isomers of gossypol, in blood plasma (Table 4). Lowest concentrations occurred, as expected, on the SSBM control diet, which contained no gossypol. Among diets containing one of the cottonseed treatments, the highest concentrations of total gossypol and gossypol isomers were observed when PCS was fed: SSBM + $\mathrm{PCS}>\mathrm{ESBM}+\mathrm{PCS}=\mathrm{SSBM}+\mathrm{UCS}+\mathrm{PCS}$. Plasma gossypol was lower on the 2 diets containing UCS than on any PCS diet. Diluting half of the UCS with PCSC did not significantly alter plasma gossypol; however, the lowest gossypol concentrations other than control were observed when cows were fed diets supplemented with only PCSC plus either SSBM or ESBM. Circulating gossypol concentration generally reflects gossypol content of the diet (Mena et al., 2001) and this also held true for the 2 gossypol isomers. Cows fed diets containing UCS had greater proportions of the $(+)$-isomer in their blood plasma as was found in that source; PCS and PCSC-containing diets gave rise to lower plasma $(+)$-gossypol and higher $(-)$-gossypol, as was found in those cottonseed materials (Table 1 ).

An interesting observation in the current study was that, although total gossypol intake was lower on SSBM + PCS $(24.5 \mathrm{~g} / \mathrm{d} ; 40 \mathrm{mg} / \mathrm{kg}$ of BW) than on SSBM + UCS $(27.4 \mathrm{~g} / \mathrm{d} ; 45 \mathrm{mg} / \mathrm{kg}$ of BW), feeding the PCS containing diet resulted in substantially greater total gossypol concentrations in the blood plasma (Table 4). McCaughey et al. (2005) found that a mean increase from 18 to $22 \mathrm{~g} / \mathrm{d}$ of total gossypol intake, resulting when $67 \%$ of dietary UCS was replaced with PCS, approximately doubled total gossypol in plasma. Santos et al. (2002) fed cows $18.3 \mathrm{~g} / \mathrm{d}$ of total gossypol as $10 \%$ dietary UCS, or $24.0 \mathrm{~g} / \mathrm{d}$ of total gossypol as $3.1 \%$ UCS (contributing $5.5 \mathrm{~g}$ total gossypol) plus 6.9\% PCS (contributing $18.5 \mathrm{~g}$ total gossypol) in the diet, and observed mean plasma gossypol concentrations of 3.1 and $7.8 \mu \mathrm{g} / \mathrm{mL}$ over the first $150 \mathrm{~d}$ of lactation. These researchers also reported substantially higher plasma gossypol concentrations in multiparous cows than in primiparous cows and observed that gossypol continued to increase over the whole 150-d sampling period (Santos et al., 2002). Much lower blood plasma gossypol concentrations were observed in our trial, with total gossypol intakes ranging from 14 to $27 \mathrm{~g} / \mathrm{d}$ (Table 4), but blood samples were collected after only $28 \mathrm{~d}$ on each experimental diet. Mena et al. (2001) reported that plasma gossypol reached a plateau after $35 \mathrm{~d}$ in cows consuming 22 to $25 \mathrm{~g} / \mathrm{d}$ of free gossypol, results that were at variance with those of Santos et al. (2002). In a follow-up study, Mena et al. (2004) observed that, at gossypol intakes similar to their earlier trial, plasma gossypol reached a plateau after about $28 \mathrm{~d}$ on treatment; plasma gossypol decreased by $87 \%$, from 4 to $0.5 \mu \mathrm{g} / \mathrm{mL}$, after cows were withdrawn for $28 \mathrm{~d}$ from the highest gossypol intake ( $42 \mathrm{~g} / \mathrm{d}$ of total gossypol, $21 \mathrm{~g} / \mathrm{d}$ of free gossypol). Dowd and Calhoun (1996) found that the decline of gossypol concentrations in blood plasma and several tissues in lambs fed gossypol was described by 2 first-order rates; plasma total gossypol decreased by $75 \%$, from 8 to about $2 \mu \mathrm{g} / \mathrm{mL}$ in $15 \mathrm{~d}$, and then declined more slowly. Low plasma gossypol on the SSBM control in the present experiment reflected carryover from previous periods of the Latin square. Mean total gossypol concentration measured after period 1 (in which cows consumed no cottonseed material) was $0.15 \mu \mathrm{g} / \mathrm{mL}$; plasma total gossypol on this treatment averaged $0.45 \mu \mathrm{g} / \mathrm{mL}$ over the whole trial (Table 4). However, total plasma gossypol concentrations at the end of period 1 were very similar to the overall means for the other 7 treatments (Table 4). The overall mean gossypol concentration on the 7 cottonseed-containing diets was $1.82 \mu \mathrm{g} / \mathrm{mL}$. If we assume that this represents the mean plasma gossypol concentration before switching to the SSBM control treatment, which had mean $0.45 \mu \mathrm{g} / \mathrm{mL}$, then total gossypol declined approximately $75 \%$ in $28 \mathrm{~d}$, implying a slower rate of turnover of plasma gossypol than was reported by Mena et al. (2004). This also suggested that plasma gossypol remaining in cows fed the SSBM control was influenced at least in part by the second, slower turnover pool detected by Dowd and Calhoun (1996). High levels of feed intake and milk production indicated that, under the conditions of our short-term reversal trial, there were no adverse animal effects of gossypol. It is noted that Mena et al. (2004) reported 
that, compared with a control with zero gossypol, red blood cell fragility was increased at any concentration of blood gossypol, ranging from 0.8 to $3.6 \mu \mathrm{g} / \mathrm{mL}$ of plasma; however, those researchers also observed little change in serum enzymes indicative of impaired liver, kidney, and muscle cell viability.

\section{Excretion and Nutrient Digestibility}

Fecal and urinary $\mathrm{N}$ excretion and nutrient digestibility, estimated using internal markers, are reported in Table 5. Fecal N-excretion ranged from 183 to 216 $\mathrm{g} / \mathrm{d}$ and was influenced by $\operatorname{diet}(P=0.02)$; however, there did not appear to be a specific pattern attributable to the source of supplemental CP. For example, the SSBM control and SSBM + PCSC diets both gave rise to about equal fecal $\mathrm{N}$-excretion. Although urine volume was affected by treatment $(P=0.02)$, excretion of urea- $\mathrm{N}$ and total $\mathrm{N}$, as well as proportion of urea- $\mathrm{N}$ in total- $\mathrm{N}$ excretion, were not affected by source of supplemental CP ( $P \geq 0.21)$. Reducing urinary urea- $\mathrm{N}$ excretion is important because it is the form most rapidly degraded to ammonia and then volatilized to the environment (Van Horn et al., 1994). The relatively high N-efficiencies (Table 4) observed in this trial were reflected in low proportions of urea$\mathrm{N}$, which ranged from 47 to $58 \%$ of total urinary $\mathrm{N}$ (Table 5). Olmos Colmenero and Broderick (2006) reported that urea increased from 55 to $82 \%$ of total urinary $\mathrm{N}$ when dietary $\mathrm{CP}$ increased from 13.5 to $19.4 \%$ CP. In the current study, apparent digestibility of DM, OM, NDF, and ADF were also not affected by dietary source of supplemental CP. Overall mean NDF and ADF digestibility (about 48\%) were comparable to those observed earlier on diets containing $60 \%$ total forage from similar proportions of alfalfa and corn silages (Chen et al., 2011). Similar fiber digestibility on diets with equivalent NDF and ADF from UCS, PCS, or PCSC indicated no advantage for upland versus Pima cottonseed in this trial. However, apparent $\mathrm{N}$ digestibility ranged from $65 \%$ (SSBM control and $\mathrm{ESBM}+\mathrm{PCSC})$ to $70 \%(\mathrm{SSBM}+\mathrm{PCS})$. Differences in DMI (Table 4) may have partly influenced observed apparent $\mathrm{N}$ digestibilities; thus, true $\mathrm{N}$ digestibility was computed using the NRC (2001) estimate of $4.8 \mathrm{~g}$ of metabolic fecal $\mathrm{N} / \mathrm{kg}$ of DMI (Table 5). A range of 5 percentage units was still observed after this adjustment. Among the 4 diets supplemented with SSBM or SSBM plus a single cottonseed, estimated true N digestibility was greater on SSBM + PCS, suggesting that $\mathrm{N}$ digestibility of PCS may have exceeded that of SSBM, UCS, and PCSC. It was noted that estimated true $\mathrm{N}$ digestibility on diets containing SSBM plus 2 different cottonseed materials was not different from that on SSBM + PCS, and that estimated true N digestibility on the 2 diets containing ESBM were not different from the SSBM control.

\section{Ruminal Metabolites}

Effects of experimental diets on mean concentrations of metabolites in the rumen are given in Table 6 . We

Table 5. Effects of source of supplemental protein on excretion and apparent digestibility ${ }^{1}$

\begin{tabular}{|c|c|c|c|c|c|c|c|c|c|c|}
\hline \multirow[b]{2}{*}{ Item } & \multicolumn{8}{|c|}{ Supplemental protein } & \multirow[b]{2}{*}{$\mathrm{SE}$} & \multirow[b]{2}{*}{$\begin{array}{l}\text { Diet }^{2} \\
P>\mathrm{F}\end{array}$} \\
\hline & SSBM & $\underset{\mathrm{UCS}}{\mathrm{SSBM}}+$ & $\begin{array}{c}\mathrm{SSBM}+ \\
\mathrm{PCS}\end{array}$ & $\begin{array}{l}\mathrm{SSBM}+ \\
\mathrm{PCSC}\end{array}$ & $\begin{array}{c}\mathrm{SSBM}+ \\
\mathrm{UCS}+\mathrm{PCS}\end{array}$ & $\begin{array}{c}\mathrm{SSBM}+ \\
\mathrm{UCS}+\mathrm{PCSC}\end{array}$ & $\underset{\text { PCS }}{\mathrm{ESBM}}+$ & $\begin{array}{c}\mathrm{ESBM}+ \\
\mathrm{PCSC}\end{array}$ & & \\
\hline \multicolumn{11}{|l|}{ Excretion $^{3}$} \\
\hline Fecal-N, g/d & $214.2^{\mathrm{a}}$ & $210.9^{\mathrm{ab}}$ & $182.9^{c}$ & $216.1^{\mathrm{a}}$ & $194.2^{\mathrm{bc}}$ & $202.9^{\mathrm{abc}}$ & $212.2^{\mathrm{ab}}$ & $212.6^{\mathrm{ab}}$ & 8.17 & 0.02 \\
\hline Urine volume, L/d & $26.4^{\mathrm{b}}$ & $26.0^{\mathrm{b}}$ & $30.7^{\mathrm{a}}$ & $26.7^{\mathrm{ab}}$ & $29.6^{\mathrm{ab}}$ & $25.0^{\mathrm{b}}$ & $29.6^{\mathrm{ab}}$ & $29.3^{\mathrm{ab}}$ & 1.48 & 0.02 \\
\hline Urinary urea-N, g/d & 75.9 & 89.2 & 90.7 & 86.3 & 93.0 & 91.5 & 89.7 & 83.0 & 5.03 & 0.21 \\
\hline Total urinary-N, g/d & 164.6 & 162.2 & 181.6 & 168.9 & 172.9 & 168.4 & 172.6 & 175.6 & 6.41 & 0.43 \\
\hline Urea-N/total-N, \% & 47.2 & 58.2 & 51.8 & 51.5 & 55.0 & 54.2 & 52.9 & 49.5 & 2.95 & 0.22 \\
\hline \multicolumn{11}{|l|}{ Digestibility, \% } \\
\hline Apparent DM & 68.9 & 70.5 & 71.9 & 69.6 & 70.2 & 70.8 & 69.2 & 69.8 & 0.84 & 0.21 \\
\hline Apparent OM & 70.5 & 72.0 & 73.2 & 71.1 & 71.7 & 72.4 & 70.7 & 71.3 & 0.79 & 0.21 \\
\hline Apparent NDF & 47.0 & 51.2 & 49.7 & 47.4 & 47.6 & 48.7 & 47.7 & 48.3 & 1.32 & 0.26 \\
\hline Apparent ADF & 47.5 & 50.7 & 48.8 & 47.3 & 46.1 & 48.0 & 45.5 & 47.1 & 1.32 & 0.14 \\
\hline Apparent N & $64.9^{\mathrm{c}}$ & $66.4^{\mathrm{bc}}$ & $70.1^{\mathrm{a}}$ & $66.0^{\mathrm{bc}}$ & $68.3^{\mathrm{ab}}$ & $67.6^{\mathrm{abc}}$ & $66.0^{\mathrm{bc}}$ & $64.9^{\mathrm{c}}$ & 1.12 & 0.01 \\
\hline Estimated true $\mathrm{N}^{4}$ & $85.2^{\mathrm{d}}$ & $86.8^{\mathrm{bcd}}$ & $90.4^{\mathrm{a}}$ & $86.3^{\mathrm{bdc}}$ & $88.7^{\mathrm{ab}}$ & $88.0^{\mathrm{abc}}$ & $86.4^{\mathrm{bcd}}$ & $85.3^{\mathrm{d}}$ & 0.70 & $<0.01$ \\
\hline
\end{tabular}

\footnotetext{
${ }^{\mathrm{a}-\mathrm{d}}$ Means within a row with different superscripts differ $(P<0.05)$.

${ }^{1}$ Sources of supplemental CP: SSBM = solvent soybean meal, ESBM = expeller soybean meal (SoyPlus, West Central Coop, Ralston, IA), UCS $=$ upland cottonseed, PCS = cracked Pima cottonseed, PCSC = Pima cottonseed cake (extruded).

${ }^{2}$ Probability of a significant effect of diet.

${ }^{3}$ Fecal excretion estimated using indigestible ADF as an internal marker (Cochran et al., 1986). Urine volume and urinary N excretion estimated using creatinine as an internal marker assuming $29 \mathrm{mg}$ of creatinine excreted/kg of BW per day (Valadares et al., 1999).

${ }^{4}$ True N digestibility estimated assuming $4.8 \mathrm{~g}$ of metabolic fecal $\mathrm{N}$ excreted/kg of DMI (NRC, 2001).
} 
Table 6. Effects of source of supplemental protein on ruminal $\mathrm{pH}$ and metabolite concentration ${ }^{1}$

\begin{tabular}{|c|c|c|c|c|c|c|c|c|c|c|}
\hline Item & \multicolumn{8}{|c|}{ Supplemental protein } & $\mathrm{SE}$ & $\begin{array}{l}\text { Diet }^{2} \\
P>\mathrm{F}\end{array}$ \\
\hline Ammonia-N, mg/dL & 3.9 & 4.4 & 4.1 & 4.3 & 4.5 & 4.9 & 5.0 & 3.9 & 0.45 & 0.40 \\
\hline Total AA, $\mathrm{m} M$ & 2.5 & 2.3 & 2.4 & 2.5 & 2.6 & 2.3 & 3.0 & 2.3 & 0.34 & 0.73 \\
\hline Total VFA, $\mathrm{m} M$ & 114.6 & 114.5 & 115.1 & 109.9 & 115.0 & 113.9 & 110.2 & 117.3 & 3.10 & 0.51 \\
\hline Ac:Pr ratio & 2.68 & 2.66 & 2.72 & 2.93 & 2.66 & 2.75 & 2.82 & 2.60 & 0.116 & 0.27 \\
\hline Butyrate, $\mathrm{m} M$ & 13.8 & 12.5 & 12.7 & 12.8 & 12.8 & 12.5 & 12.1 & 13.5 & 0.72 & 0.63 \\
\hline Isobutyrate, $\mathrm{m} M$ & 1.25 & 1.32 & 1.32 & 1.18 & 1.27 & 1.28 & 1.24 & 1.22 & 0.044 & 0.09 \\
\hline $\begin{array}{l}\text { Isovalerate }+ \\
2 \text {-methyl butyrate, } \mathrm{m} M\end{array}$ & 1.93 & 2.40 & 2.34 & 2.14 & 2.24 & 2.25 & 2.27 & 2.02 & 0.179 & 0.07 \\
\hline $\mathrm{BCVFA},{ }^{3} \mathrm{~m} M$ & $3.18^{\mathrm{b}}$ & $3.71^{\mathrm{a}}$ & $3.67^{\mathrm{a}}$ & $3.32^{\mathrm{b}}$ & $3.51^{\mathrm{ab}}$ & $3.53^{\mathrm{ab}}$ & $3.51^{\mathrm{ab}}$ & $3.24^{\mathrm{b}}$ & 0.210 & 0.04 \\
\hline Valerate, $\mathrm{m} M$ & 2.04 & 1.95 & 1.92 & 1.82 & 1.84 & 1.95 & 1.80 & 2.14 & 0.075 & 0.08 \\
\hline
\end{tabular}

${ }_{\mathrm{a}, \mathrm{b}}$ Means within a row with different superscripts differ $(P<0.05)$.

${ }^{1}$ Sources of supplemental CP: SSBM = solvent soybean meal, ESBM = expeller soybean meal (SoyPlus, West Central Coop, Ralston, IA), UCS $=$ upland cottonseed, PCS = cracked Pima cottonseed, PCSC = Pima cottonseed cake (extruded).

${ }^{2}$ Probability of a significant effect of diet.

${ }^{3}$ Branched-chain VFA (isobutyrate and isovalerate +2 -methyl butyrate).

found no significant effects on most traits, with average $\mathrm{pH}$ of 6.67 , and typical mean concentrations of total VFA $(114 \mathrm{mM})$, acetate $(69 \mathrm{mM})$, propionate $(26 \mathrm{mM})$, and butyrate $(13 \mathrm{mM})$, and acetate:propionate ratio (2.7). Low ruminal ammonia and total AA reflected the low CP diets fed in this study. However, we did observe trends $(P \leq 0.09)$ for dietary effects on ruminal concentrations of isobutyrate and isovalerate +2 -methylbutyrate, and we detected significant effects of diet on the small differences in total branched-chain VFA (BCVFA). Lowest BCVFA were observed on the SSBM control and on the 2 diets in which $50 \%$ of supplemental CP was provided by PCSC. Highest BCVFA were found on SSBM + UCS and SSBM + PCS, with the other diets being intermediate. The BCVFA are formed from microbial catabolism of the branched-chain AA, and reduced concentrations of BCVFA reflect reduced ruminal protein degradation (Van Soest, 1994). Our results suggested that the experimental extrusion process decreased ruminal degradation of protein in the PCSC supplement. That BCVFA were not different due to soybean meal source on the PCSC diets (SSBM + PCSC vs. ESBM + PCSC) suggested that the lack of positive response with addition of PCSC to ESBM was not caused by inadequate RDP supply. Pena et al. (1986) found that extruding UCS (maximum temperature $=150^{\circ} \mathrm{C}$, decreasing to $95^{\circ} \mathrm{C}$ in $30 \mathrm{~s}$ and to ambient temperature in 5-10 min) also decreased ruminal BCV$\mathrm{FA}$ and increased duodenal flow of nonammonia $\mathrm{N}$ by $20 \%$ in cannulated dairy cows. Tagari et al. (1986) and Stutts et al. (1988) both reported decreased ruminal degradation of protein in extruded whole cottonseed as assessed by in situ methodology.

\section{CONCLUSIONS}

A lactation trial was conducted to assess the nutritional value for dairy cattle of UCS, PCS, and PCSC (i.e., PCS processed by an experimental extrusion process) as supplements to soybean meal. Extrusion reduced fat content by $73 \%$, increased concentrations of $\mathrm{CP}, \mathrm{NDF}$, and ADF, and reduced concentration of total gossypol, (+)-gossypol, and (-)-gossypol in PCSC versus PCS. Replacing half of the supplemental dietary CP from SSBM with CP from UCS, PCS, PCSC, UCS plus PCS, or UCS plus PCSC, or replacing SSBM with CP from ESBM plus PCS or ESBM plus PCSC influenced DMI, and intake generally increased with addition of cottonseed materials. Feeding the greatest amounts of cottonseed oil increased milk fat content and yield in this trial. Milk protein content was also influenced by dietary treatment. The greatest fat yield and the numerically highest yields of milk, ECM, and milk protein occurred on the diet supplemented with ESBM plus PCS. Reduced concentrations of BCVFA in the rumen suggested reduced degradation of PCSC protein. Concentrations of total gossypol, and both $(+)$ - and (-)-isomers of gossypol, were higher in blood plasma on PCS, and lower on PCSC, than on corresponding diets containing UCS, indicating that the extrusion process reduced gossypol absorption. In this trial, production of milk and milk components on diets 
supplemented with UCS, PCS, or PCSC was comparable to that on diets containing supplemental $\mathrm{CP}$ as SSBM alone. The extrusion process appeared to reduce gossypol absorption from PCS and may have increased ruminal protein escape.

\section{ACKNOWLEDGMENTS}

The authors thank Alberto Pando and the board of Mesa Farmers Cooperative Gin (Vado, NM) for providing the cottonseed and their cooperation in this work; Daniel Hirschler and Continental Agra Equipment (Newton, KS) for technical assistance with extrusion; the staff of the USDA-ARS Southwestern Cotton Ginning Research Laboratory (SWCGRL, Mesilla Park, NM) for assistance with extruding the cottonseed; Nancy Betzold and her barn crew at the US Dairy Forage Research Center Farm (Prairie du Sac, WI) for feeding and animal care during this trial; Wendy Radloff and Mary Becker of the US Dairy Forage Research Center (Madison, WI) for laboratory analyses; Peter Crump of the University of Wisconsin-Madison for assisting with statistical analyses; and the USDA Small Business Innovation Research (SBIR) grant program for partial funding of the project.

\section{REFERENCES}

American Oil Chemists' Society (AOCS). 1998. Official Methods and Recommended Practices of the American Oil Chemists' Society. D. Firestone, ed. AOCS Press, Champaign, IL.

AOAC. 1980. Official Methods of Analysis. 13th ed. Association of Official Analytical Chemists, Washington, DC.

AOAC. 1990. Official Methods of Analysis. 15th ed. Association of Official Analytical Chemists, Washington, DC.

AOAC International. 1997. Official Methods of Analysis. 16th ed. AOAC International, Arlington, VA.

Brito, A. F., and G. A. Broderick. 2007. Effects of feeding different protein supplements on milk production and nutrient utilization in dairy cows. J. Dairy Sci. 90:1816-1827.

Broderick, G. A. 1987. Determination of protein degradation rates using a rumen in vitro system containing inhibitors of microbial nitrogen metabolism. Br. J. Nutr. 58:463-475.

Broderick, G. A. 1995. Desirable characteristics of forage legumes for improving protein utilization in ruminants. J. Anim. Sci. $73: 2760-2773$.

Broderick, G. A., and M. K. Clayton. 1997. A statistical evaluation of animal and nutritional factors influencing concentrations of milk urea nitrogen. J. Dairy Sci. 80:2964-2971.

Broderick, G. A., M. J. Stevenson, R. A. Patton, N. E. Lobos, and J. J. Olmos Colmenero. 2008. Effect of supplementing rumen-protected methionine on production and nitrogen excretion in lactating dairy cows. J. Dairy Sci. 91:1092-1102.

Bullock, S. L., D. G. Hewitt, R. L. Stanko, M. K. Dowd, J. Rutledge, and D. A. Draeger. 2010. Plasma gossypol dynamics in whitetailed deer: Implications for whole cottonseed as a supplemental feed. Small Rumin. Res. 93:165-170.

Chen, Z. H., G. A. Broderick, N. D. Luchini, B. K. Sloan, and E. Devillard. 2011. Effect of feeding different sources of rumen-protected methionine on milk production and $\mathrm{N}$-utilization in lactating dairy cows. J. Dairy Sci. 94:1978-1988.
Coblentz, W. K., P. C. Hoffman, and N. P. Martin. 2010. Effects of spontaneous heating on forage protein fractions and in situ disappearance kinetics of crude protein for alfalfa-orchardgrass hays packaged in large round bales. J. Dairy Sci. 93:1148-1169.

Cochran, R. C., D. C. Adams, J. D. Wallace, and M. L. Galyean. 1986. Predicting digestibility of different diet with internal markers: Evaluation of four potential markers. J. Anim. Sci. 63:1476-1487.

Coppock, C. E., J. K. Lanham, and J. I. Horner. 1987. A review of the nutritive value and utilization of whole cottonseed, cottonseed meal and associated by-products by dairy cattle. Anim. Feed Sci. Technol. 18:89-129.

Craig, W. M., and G. A. Broderick. 1981. Effect of heat-treatment on true digestibility, in vitro digestibility and available lysine content of cottonseed meal protein. J. Anim. Sci. 52:292-301.

Dowd, M. K., and M. C. Calhoun. 1996. Uptake and depletion of gossypol by the tissues of Rambouillet lambs. [Abstract title.] Proc. 45th Oilseed Conf., New Orleans, LA. National Cottonseed Products Association, Cordova, TN.

Hintz, R. W., D. R. Mertens, and K. A. Albrecht. 1996. Effects of sodium sulfite on recovery and composition of detergent fiber and lignin. J. AOAC Int. 79:16-22.

Huhtanen, P., K. Kaustell, and S. Jaakkola. 1994. The use of internal markers to predict total digestibility and duodenal flow of nutrients in cattle given six different diets. Anim. Feed Sci. Technol. 48:211-227.

Krause, K. M., and D. K. Combs. 2003. Effects of forage particle size, forage source, and grain fermentability on performance and ruminal pH in midlactation cows. J. Dairy Sci. 86:1382-1397.

Licitra, G., T. M. Hernandez, and P. J. Van Soest. 1996. Standardization of procedures for nitrogen fractionation of ruminant feeds. Anim. Feed Sci. Technol. 57:347-358.

McCaughey, K. M., E. J. DePeters, P. H. Robinson, J. E. P. Santos, J. W. Pareas, and S. J. Taylor. 2005. Impact of feeding whole Upland cottonseed, with or without cracked Pima cottonseed with increasing addition of iron sulfate, on productivity and plasma gossypol of lactating dairy cattle. Anim. Feed Sci. Technol. 122:241-256.

McDonald, P., A. R. Henderson, and S. J. E. Heron. 1991. The Biochemistry of Silage. Chalcombe Publications, Marlow, UK.

Mena, H., J. E. P. Santos, J. T. Huber, J. M. Simas, M. Tarazon, and M. C. Calhoun. 2001. The effects of feeding varying amounts of gossypol from whole cottonseed and cottonseed meal in lactating dairy cows. J. Dairy Sci. 84:2231-2239.

Mena, H., J. E. P. Santos, J. T. Huber, M. Tarazon, and M. C. Calhoun. 2004. The effects of varying gossypol intake from whole cottonseed and cottonseed meal on lactation and blood parameters in lactating dairy cows. J. Dairy Sci. 87:2506-2518.

Mohamed, O. E., L. D. Satter, R. R. Grummer, and F. R. Ehle. 1988. Influence of dietary cottonseed and soybean on milk production and composition. J. Dairy Sci. 71:2677-2688.

Muck, R. E. 1987. Dry matter level effects on alfalfa silage quality. 1. Nitrogen transformations. Trans. Am. Soc. Agric. Eng. 30:7-14.

Nousiainen, J., K. J. Shingfield, and P. Huhtanen. 2004. Evaluation of milk urea nitrogen as a diagnostic of protein feeding. J. Dairy Sci. $87: 386-398$.

NRC. 2001. Nutrient Requirements of Dairy Cattle. 7th rev. ed. Natl. Acad. Sci., Washington, DC.

Olmos Colmenero, J. J., and G. A. Broderick. 2006. Effect of dietary crude protein concentration on milk production and nitrogen utilization in lactating dairy cows. J. Dairy Sci. 89:1704-1712.

Pena, F., H. Tagari, and L. D. Satter. 1986. The effect of heat treatment of whole cottonseed on site and extent of protein digestion in dairy cows. J. Anim. Sci. 62:1423-1433.

Pettigrew, W. T., and M. K. Dowd. 2011. Varying planting dates or irrigation regimes alters cottonseed composition. Crop Sci. $51: 2155-2164$.

Prieto, J. G., E. J. DePeters, P. H. Robinson, J. E. P. Santos, J. W. Pareas, and S. J. Taylor. 2003. Increasing dietary levels of cracked Pima cottonseed increase plasma gossypol but do not influence productive performance of lactating Holstein cows. J. Dairy Sci. $86: 254-267$. 
Roth, M. 1971. Fluorescence reaction of amino acids. Anal. Chem. 43:880-882.

Santos, J. E. P., H. Mena, J. T. Huber, and M. Tarazon. 2005. Effects of source of gossypol and supplemental iron on plasma gossypol in Holstein steers. J. Dairy Sci. 88:3563-3574.

Santos, J. E. P., M. Villasenor, E. J. DePeters, P. H. Robinson, and B. C. Baldwin Jr.. 2002. Type of cottonseed and level of gossypol in diets of lactating dairy cows: effects on lactation performance and plasma gossypol. J. Dairy Sci. 85:1491-1501.

SAS Institute. 1999-2000. SAS/STAT User's Guide. Release 8.1. SAS Institute Inc., Cary, NC.

Scheffler, J. A., and G. B. Romano. 2008. Modifying gossypol in cotton (Gossypium hirsutum L.): A cost effective method for small seed samples. J. Cotton Sci. 12:202-209.

Sklan, D., R. Ashkenazi, A. Braun, A. Devorn, and K. Tabori. 1992. Fatty acids, calcium soaps of fatty acids, and cottonseeds fed to high yielding cows. J. Dairy Sci. 75:2463-2472.

Stutts, J. A., W. A. Nipper, R. W. Adkinson, J. E. Chandler, and A. S. Achacoso. 1988. Protein solubility, in vitro ammonia concentration, and in situ disappearance of extruded whole cottonseed and other protein sources. J. Dairy Sci. 71:3323-3333.

Sullivan, J. L., J. T. Huber, and J. M. Harper. 1993. Performance of dairy cows fed short staple, Pima, and cracked Pima cottonseed and feed characteristics. J. Dairy Sci. 76:3555-3561.
Tagari, H., F. Pena, and L. D. Satter. 1986. Protein degradation by rumen microbes of heat-treated whole cottonseed. J. Anim. Sci 62:1732-1736

USDA-NASS (US Department of Agriculture-National Agricultural Statistics Service). 2011. Cotton Ginnings (03.23.2012). USDA-NASS, Washington, DC. Accessed Apr. 30, 2012. http:// usda.mannlib.cornell.edu/MannUsda/viewDocumentInfo. do?documentID $=1041$.

Valadares, R. F., G. A. Broderick, S. C. Valadares, and M. K. Clayton. 1999. Effect of replacing alfalfa silage with high moisture corn on ruminal protein synthesis estimated from excretion of total purine derivatives. J. Dairy Sci. 82:2686-2696.

Van Horn, H. H., A. C. Wilkie, W. J. Powers, and R. A. Norstedt. 1994. Components of dairy manure management systems. J. Dairy Sci. 77:2008-2030.

Van Soest, P. J. 1994. Nutritional Ecology of the Ruminant. 2nd ed. O \& B Books Inc., Corvallis, OR.

Van Soest, P. J., J. B. Robertson, and B. A. Lewis. 1991. Methods for dietary fiber, neutral detergent fiber, and nonstarch polysaccharides in relation to animal nutrition. J. Dairy Sci. 74:3583-3597.

Vanhatalo, A., P. Huhtanen, V. Toivonen, and T. Varvikko. 1999. Response of dairy cows fed grass silage diets to abomasal infusions of histidine alone or in combinations with methionine and lysine. J. Dairy Sci. 82:2674-2685. 